\title{
イオン交換樹脂を用いる緑膿菌 autolysate
}

\section{よりの内毒素の分離精製}

\section{Application of Ion Exchange Resins for the Isolation and Purification of the Endotoxin of Pseudomonas Aeruginosa from Its fluid Culture Media}

\author{
東京大学伝染病研究所第一細菌 \\ 現在 群馬大学医学部衞生学教室 \\ 芦 沢 義 郎 \\ Yoshio Ashizawa
}

(First Division, The Institute for Infectious Diseses, University of Tokyo.)

Present address: Department of Hygiene, School of

Medicine, Gunma University.

\section{緒 言}

グラム陰性桿菌より内毒素を分離する方法は周知のご とく Boivin の方法を始就をする化学試薬による菌体よ りの抽出分離で，その意図するととろは要するに菌体蛋 白を変性あるいは破壊して糖脂体を主体とする内毒素を 分離しょうとするものであつた ${ }^{1-9)}$ 。

とれに対してさき汇細谷, 本間ら緑膿菌を用い, そ の autolysate (自家融解液) から，なる心゙く菌体蛋白の 変性をさけて内毒素を分離する方法を試みた。Cの方法 は従来細谷宮田法として単純蛋白である菌体外毒素の分 離精製汇使用されていたものであるが，とれを内毒素の 分離に初めて応用したものである10-11。

更に本間，江上らは精製過程に electrodialysis，zone electrophoresis 忘用するとこによつて lipopolysaccharide-protein complex (comp. I と命名) と nucleic acids-polyribose phosphate (comp. II と命名)をとれぞれ単 離するととが出来た。またとの結果 autolysate 中には comp. I と comp. II とが結合して存在し，とれに更に塩 基性物質が結合しているととを明らかにした ${ }^{12-18) 。 ~}$

本論交怯 autolysate から直接にイオン交換樹脂を用い て有毒成分であるcomp. Iの分離精製の可能性を検討し たものである。との目的のためまず従来の細谷, 本間ら の方法でえられた精製内毒素のイオン交換樹脂による吸
着溶出をこころみた。ついでとのデーターを基礎として autolysate 亦ら直接に分離を試及とれ成功した。

\section{実験材料}

精製菌体内毒素：前報に記載した方法で分離した精製 内毒素を使用した20)。

土島株 (A 3 株) を下記組成の合成培地

組成:グルタミン酸ソーダ $2 \%$

$\begin{array}{ll}\text { グルコース } & 0.5 \\ \mathrm{MgSO}_{4}-7 \mathrm{H}_{2} \mathrm{O} & 0.01 \\ \mathrm{Ca}\left(\mathrm{NO}_{3}\right)_{2} & 0.0001 \\ \mathrm{FeSO}_{4}-7 \mathrm{H}_{2} \mathrm{O} & 0.000005 \\ \mathrm{Na}_{2} \mathrm{HPO}_{4}-12 \mathrm{H}_{2} \mathrm{O} & 0.563 \\ \mathrm{KH}_{2} \mathrm{PO}_{4} & 0.0252\end{array}$

$\mathrm{pH} 7.6$

にうえ, $37^{\circ} \mathrm{C}$ に3 時間振盪培養しトルエンを重層し $37^{\circ} \mathrm{C}$ に更に 40 時間静置する。滤紙滤過後シャープレス超遠心 器で菌体を除き, その滤液を $\mathrm{ZnCl}_{2}-\mathrm{Na}_{2} \mathrm{HPO}$ ，用いる 細谷法て濃縮し普通透析, 電気透析を扣こない, その内 液よりアセトン沈降沉よつて精製内毒素を分離した。

これらは電気泳動的汇均一である。た燐量を加減し 培地 $1 \mathrm{ml}$ 当り $30 \mu \mathrm{g}$ とし, Сれそ $\mathrm{P}^{32}$ を加え培養すると とにより同様の方法で $\mathrm{P}^{32}$ ラベル付内毒素を分離し ${ }^{14)}$ 実 験汇使用した。 
イオン交換樹脂：Amberleite IRA 410, I RA 400, IR 4 B, Narcite WBR, Dowex 50, Amberleite IRC 50，XE64使用した。

内毒素の定量 : 放射性内毒素の $\mathrm{P}^{32}$ 放射能を GeigerMüller Counter により測定し 比放射能加 毒素量を算 定した。同時に内瑇素を Folin 反応により定量した ${ }^{21}$ 。 更に沈降反応も抢てなつて参考とした。

\section{実 験}

\section{I. 精製内毒素のイオン交換樹脂による吸㟶と溶出}

塩基性樹脂である Amberleite IRA 410， IRA 400, IR 4 B， Nalcite WBR などの $\mathrm{PO}_{4}$ 型在用いた場合， 中性溶液で内毒素没完全に吸着される。いろいろの条件 での溶出を試みたが成功できなかつた。酸性樹脂である Dowex 50, Amberleite IRC 50，XE64亿対しては中性 乃至弱アルカリ性では吸着されない。酸性側では $\mathrm{pH} 1$ 〜 2 附近で最もよく吸着される。Amberleite XE 64 を 用いた成績焒Fig. 1 亿示した。また Dowex 50を用いた 成績岵 Fig. 2 亿示した。吸着された毒素㹥 $0.4 \mathrm{~N} \cdot \mathrm{NaOH}$ で $\mathrm{pH} 7$ Kすることにより添とんど完全に溶出できた

Fig. $1 \mathrm{P}^{32}$ ラベル付内玨素の Amberleite XE-64 への吸畨

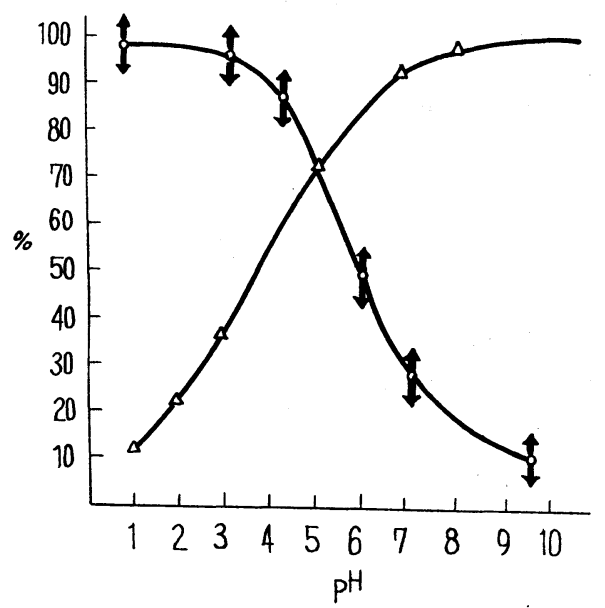

一定量の $\mathrm{P}^{32}$ ラぶル付内毒素を燐酸ソーダあるいは クェン酸緩衝液で, それぞれの pH bufferize した XE 64 と共に振盜し上清に残つた末吸着毒素量を $\mathrm{P}^{32}$ の比放射能から算出した。四は毒素とレジン振 盜上清の未吸着毒素を量を縦軸に示したものである。 autolysate 中の抗原物質は沈降反応から概算した。 矢印はその誤差範囲を示した。

$\triangle \longrightarrow \triangle \mathrm{P}^{32}$ ラヘル付内毒素

$\bigcirc$ - $\bigcirc$ autolysate 中の抗原物質
Eig. $2 \mathbf{P}^{32}$ ラベル付内毒素の Dowex 50 に対する吸前

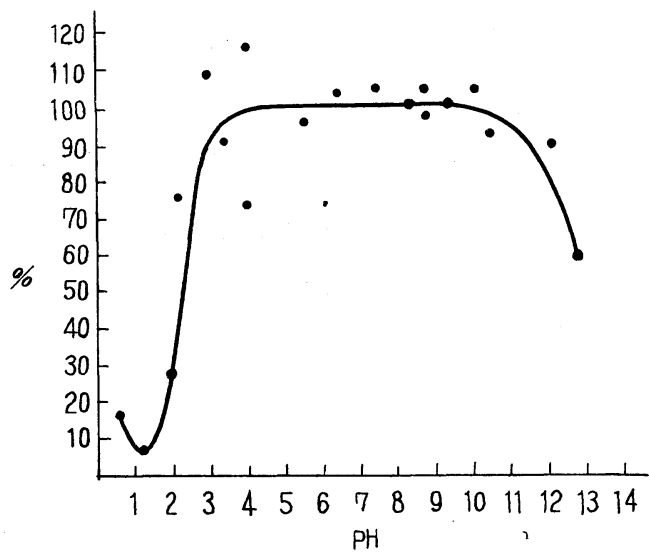

Dowex 50 (Na 型) $2 \mathrm{~g}$ をいろいろの pH の buffer で処置し $\mathrm{P}^{32}$ ラベル付内毒素 $150 \mu \mathrm{g}(0.5 \mathrm{ml})$ を加え， これに蒸溜水を加えて全景を $10 \mathrm{ml}$ とする，振盪 30 分後その上清 $1 \mathrm{ml}$ を測定血にとり乾燥, 放射能を 測定した。上清の毒素量は比放射能から算出し，そ の未吸着量 $(\%)$ を縦軸に $\mathrm{pH}$ を横軸に示した。

以下Amberleite XE 64を使用した実験成績を示す。まず $\mathrm{XE64}$ をクエン酸緩衝液て $\mathrm{pH} 2.2$ とし内毒素溶液 $(\mathrm{pH}$ 2.2）を流して吸着させるとレジン $1 \mathrm{~g}$ 当り 4 〜 $\mathrm{mg}$ の内毒素が吸着される。そこで本実験ではレジン $1 \mathrm{~g}$ 当 り $3 \mathrm{mg}$ の内毒素を使用した。溶出伎 $0.4 \mathrm{~N}-\mathrm{NaOH} て$ 置換クロマトの方法をとつた。実験結果快 Fig. 3 に示 したが比放射能によつて算出された溶出毒素量はほとん ど 100\%に近く，別に扮こなつた Folin 反応による比色 定量の成績も医将これと一致した。また沈降反応によつ て示される成績も大体とれと一致したので内毒素はおそ らく大した変化を受けるととなく溶出されたと推定さ れる。更に同様の実験を Fig. 4-1 亿示したが溶出液 の前半を $\mathrm{a}_{1}$ とし後半を $\mathrm{a}_{2}$ として集め, それぞれもう一度 吸着溶出を抢こないそれぞれ Fig. 4-2, Fig. 4-3亿示 した結果いずれも同じ溶出曲線をえた。また流速を毎時 $0.1 \mathrm{ml}$ としても $\mathrm{NaOH}$ の濃度を $0.01 \mathrm{~N}$ として溶出を 抢こなつたが溶出曲線に変化はみられなかつた。

そこで次に吸着溶出前後に抬ける内毒素の生物学的, 物理化学的性状の変化をみるために大量の毒素を用いて おこなつた。使用内毒素は Fig. 5 に示すように電気泳 動的に均一である。吸着溶出は前記実験と同様に扢てな つた。Fig. 6 に示したように溶出液は $\mathrm{a}_{1}, \mathrm{a}_{2}, \mathrm{a}_{3}$ ，にわけ それぞれにアセトンを加え毒素を沈降でた後, 凍結乾燥 
Fig. 3 緑膿菌内㱴素の Amberleite XE 64 に対する吸着，溶出

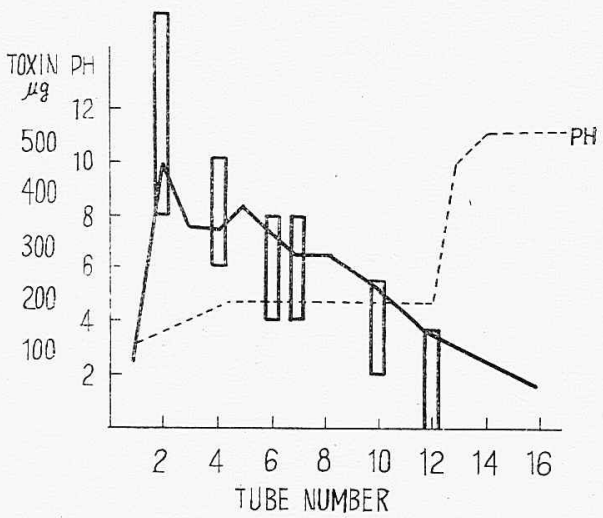

Amberleite XE $641 \mathrm{~g}$ に対して $3 \mathrm{mg}$ の割に $\mathrm{P}^{32}$ ラベル付内毒䒺を吸着させ $0.4 \mathrm{~N}-\mathrm{NaOH}$ で溶出し た。Columm $5 \times 0.8 \mathrm{~cm}$, 流速 $0.1 \mathrm{ml}$ per minute, 1 tube $5 \mathrm{ml}$.

一 $\mathrm{P}^{32}$ の比放射能から算出されを内毒素量:

抗内毒素ウサギ血清と溶出された内毒素溶液 との沈降反応から算出しえ・害素量の誼差範囲 を示す。

Fig. 4 Amberleite XE 64 に吸着した 緑膿菌内毒素の溶出曲線

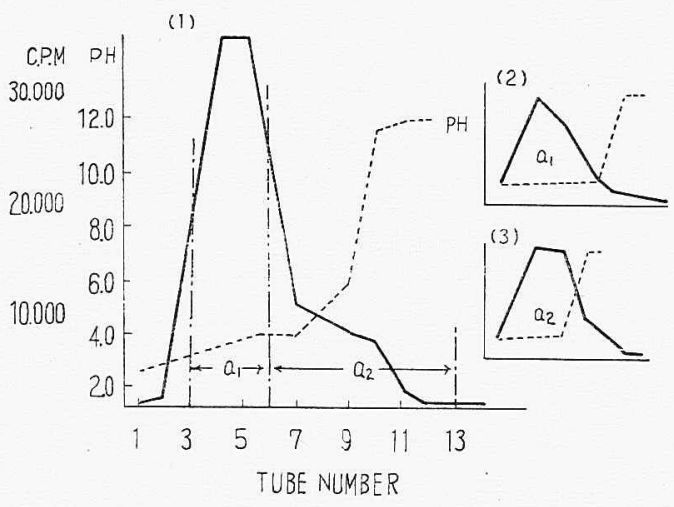

Amberleite XE $641 \mathrm{~g}$ に対して $3 \mathrm{mg}$ の割に $\mathrm{P}^{32}$ ラミル付内毒素を吸着させ $0.4 \mathrm{~N}-\mathrm{NaOH}$ で溶出し え。内毒素は $\mathrm{P}^{32}$ の比放射能から算出した。

Column $5 \times 0.8 \mathrm{~cm}$, 流速 $0.1 \mathrm{ml}$ per minute, 1 tube $5 \mathrm{ml}$ 。Fig. 4-1 の前半である試験管 No. 2-6を集め て $a_{1}$ とた。No. 7-13を集めて $a_{2}$ とした。 $a_{1}$ を同様 の操作で溶出させを多の Fig. 4-2 K示した。 同梳の操作で吸着溶出したものを Fig. 4-3 とした。
Fig.5 内毒素の電気泳動図

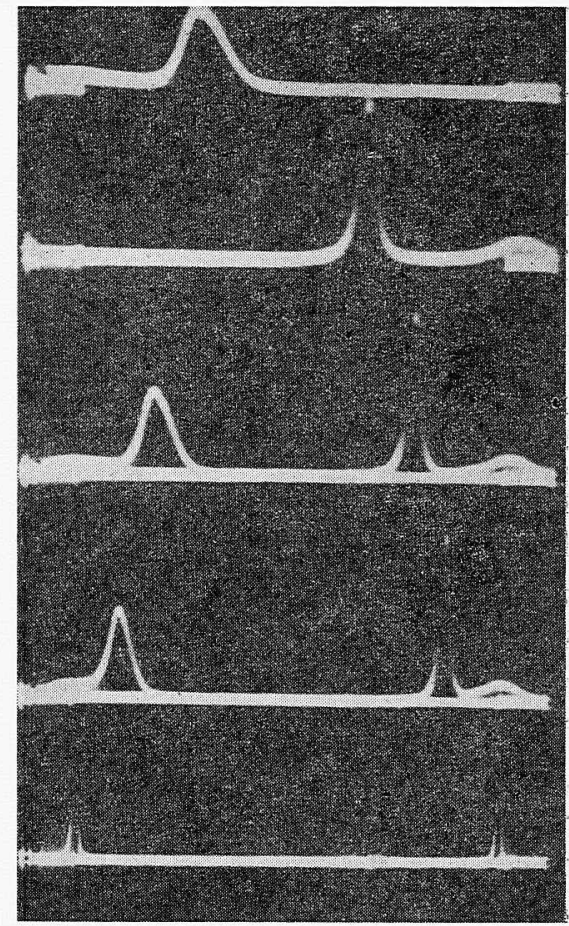

Phosphate buffer $\mathrm{pH} 7.7 \quad \mu=0.2 \quad 5^{\circ} \mathrm{C}$

Fig. 6 Amberleite XE 64 に吸着した 緑膿菌内毒素の吸着溶出

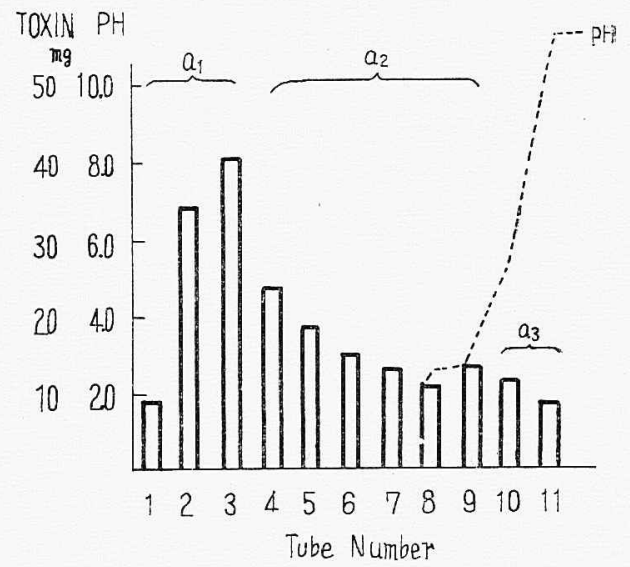

内静 $200 \mathrm{mg}$, Amberleite XE $6460 \mathrm{~g}$, Column $6 \times 40 \mathrm{~cm}$, 流速 $2 \mathrm{ml}$ per minute, $0.4 \mathrm{~N}-\mathrm{NaOH}$ で 溶出, 各 tube $100 \mathrm{ml}$, 毒素は Folin 反応により Coleman の Spectrophotometer Kよつて比色し定 㫣した。 
Table 1 Amberleite XE 64 に吸着, 溶出前後の内毒素の二, 三の化学分析值, 生物学的性状

\begin{tabular}{l|c|c|c|c|c}
\hline & $\begin{array}{r}\text { Nitrogen } \\
\%\end{array}$ & $\begin{array}{c}\text { Phosphous } \\
\%\end{array}$ & $\begin{array}{l}\text { Precipitin } \\
\text { reaction }\end{array}$ & $\begin{array}{l}\text { Minimum pre- } \\
\text { paratory dose of } \\
\text { Shwartzman reaction } \mu \mathrm{g}\end{array}$ & $\begin{array}{l}\text { Antibody production } \\
\text { (Anaphylaxy) }\end{array}$ \\
\hline $\begin{array}{l}\text { The purified endotoxin } \\
\text { before treatment }\end{array}$ & 9.2 & 2.7 & 320,000 & 0.08 & + \\
$\begin{array}{l}\text { The purified endotoxin a1 } \\
\text { after treatment }\end{array}$ & 9.2 & 2.9 & 320,000 & 0.08 & + \\
\hline
\end{tabular}

沈降反応：ウサギ抗内毒素血清に対する抗原稀积倍数で示した（重層法）。

Shwartzman 反応：ウサギ皮内に, いろいろの濃度の内毒素を含む溶液 $0.1 \mathrm{ml}$ を準備注射し 18 時間後に静 脈内に原毒素を注射, 5 時間後に判学した。

抗原性, アナフィラキシー性： $350 \mathrm{~g}$ のモルモットの皮下に $50 \mu \mathrm{g}$ 注射後 7 日目に抗体産生を認めた。更に $200 \mu \mathrm{g}$ 注射後 9 日目 $3 \mathrm{mg}$ を静脈内に注射したとてろ, 定型的アナフィラキシーショックで死亡した。

した。全収量は $76 \%$ で，えられ材料電気泳動的に均 一であつた。化学分析値, 生物学的性状の比較は Table 1 に示したが, XE 64吸着溶出前後に扔いて著しい変化 梳みられなかつた。以上の実験結果からカラム法あるい はバッチ法により内毒素は $\mathrm{pH} 2.2 て ゙$ Amberleite XE 64k完全に吸着し, $\mathrm{NaOH}$ により $\mathrm{pH} 7$ にするととによ りほとんど完全に溶出できる。回収率は毎常 $80 \%$ 前後で あつた。又吸着溶出前後に执いて物理化学的, 生物学的 性状に変化はみられなかつた。

\section{II. autolysate よりのイオン 交換樹脂を用いる内毒 素の分離精製}

前記合成培地 51 t $150 \mathrm{ml}$ づつ振盪コルベン(容量 500 $\mathrm{ml}$ ) K分注し隇菌の後, 士島株を弓え $37^{\circ} \mathrm{C}$ に 30 㭙間振盪 培養を抬てなつた。ついでトルェンを重層し 48 時間 $37^{\circ} \mathrm{C}$ に静置する。濾紙で滤過し Sharpless 超遠心機でとの autolysate より菌体残渣を除く上褐色透明の滤夜を弓 る。とれに $50 \% \mathrm{ZnCl}_{2}$ 溶液を滴下すると白色沈溉を生 ずる。よく擋拌し，む统や上清が白濁しないまで充分に 且つ可及的少量加える。Cの沈澱を傾斜及び遠心によつ て集为, $20 \% \mathrm{Na}_{2} \mathrm{HPO}_{4}$ が $\mathrm{Zn}\left(\mathrm{PO}_{4}\right)$ の白沈と完全に置 きかわるまで加えてとの 沈澱を除き濃縮毒素溶液をう る。ついでセロファン囊あるい性牛腸膜を用いて低温て 2 日流水透析を行う。内液に稀苛性ソーダを滴加し, $\mathrm{pH}$ 8.5 とし Dowex 50 ( Na 型) を加え 6 時間擋拌する。 之の漂液在 Dowex 50 六ら分け稀塩酸で $\mathrm{pH} 2.2$ とし Amberleite XE64（H型）を加え 30 分摚拌する。つい で充分に水洗ししのレジンを Column につめて $0.4 \mathrm{~N}$ $\mathrm{NaOH}$ で溶出するかあるいはこのレジンに $0.4 \mathrm{~N}-\mathrm{NaO}$ $\mathrm{H}$ を加えて中性にして溶出する。溶出液怔低温 $(0-5$ $\left.{ }^{\circ} \mathrm{C}\right)$ でアセトンを加えて沈降させ凍結乾燥する。収量恃 51 の全培養から $230 \mathrm{mg}$ えられる。(Table 2) Cの内毒 素は電気泳動的に均一である (Fig. 7) 化学分析値は

\section{Table 2}

Synthetic media, 5 liters Shake culture, $37^{\circ} \mathrm{C}$ for $30 \mathrm{hrs}$ Autolysis (Toluene) $37^{\circ} \mathrm{C}$ for 2 days Filtrate (through filter paper) Sharpless centrifuge

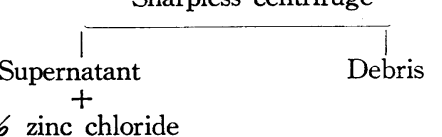

$50 \%$ zinc chloride

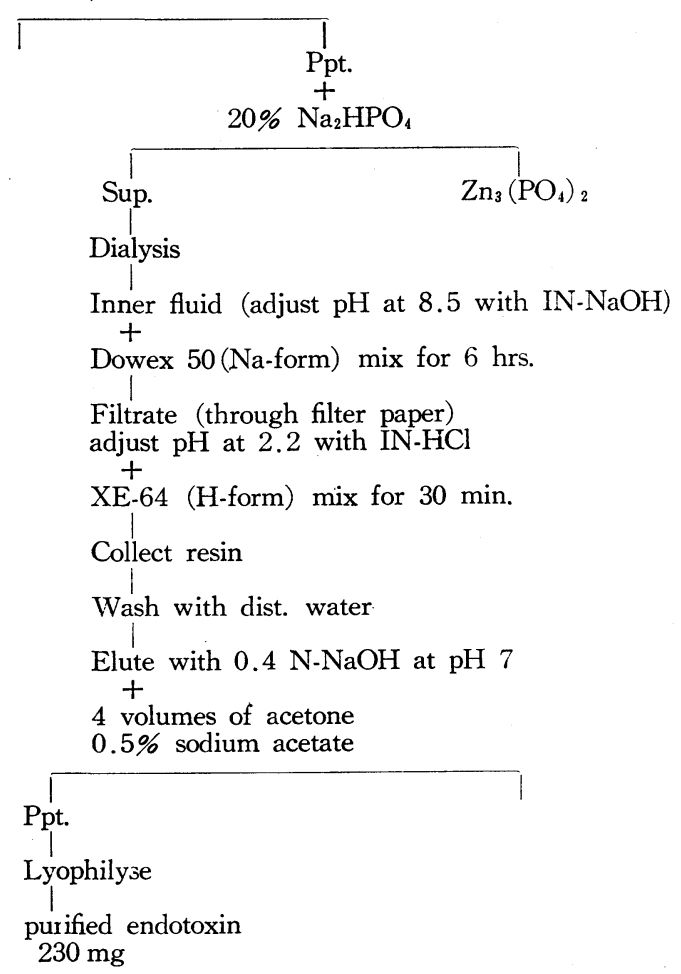


Fig. 7 レジンにより精製された内毒素 の電気泳動図

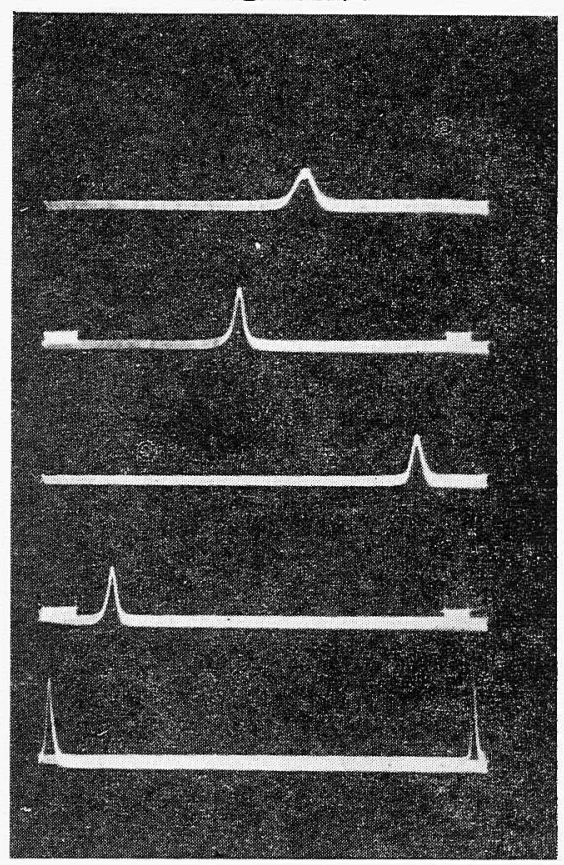

Veronal buffer pH $8.6, \mu=0.05,12^{\circ} \mathrm{C}$

Table 3

\begin{tabular}{l|l}
\hline Nirogen & $8.45 \%$ \\
Phosphorus & 1.61 \\
$\begin{array}{l}\text { Reducing sugar } \\
\text { (as glucose) }\end{array}$ & 12.0 \\
$\begin{array}{l}\text { Folin test } \\
\text { (as tyrosin) }\end{array}$ & 8.0 \\
\hline
\end{tabular}

Nitrogen : Micro Kjeldahl method

Phosphorus: R. J. L. Allen, Biochem. J., 34, 858, 1940

Reducing sugar: A. Fujita and D. Iwatake, Biochem. Z., 242, 43, 1932

Folin test: O. H. Lowry, J. Biol. Chem., 193, 265, 1951

Table 3に示した。加水分解後やーパークロマトグラフ ィーにより，リボース，デゾキシリボース，ラムノース， グルコース，アラビノース㒛めん。したがつてこの内 毒素 (comp. I) 上同椂つ性状を示し化学的には Lipopolysaccharide-protein complex 之考光られる。䄅衣紫外 部吸収曲線仗 Fig. 8 に示したが, これも従来の comp. I 己変りない。堆性沈 $L_{50} 0.3 \mathrm{mg} て ゙$ Shwartzman 反

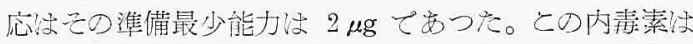
ウサ斗抗菌血清と重層法で沈降反応を抬こなつたととろ

\section{Fig. 8 紫外線吸収スペクトル}

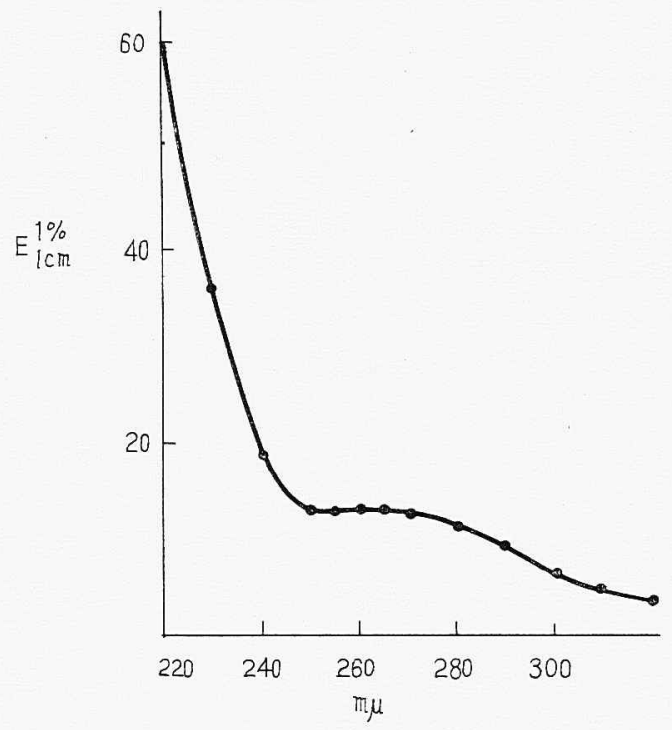

Beckmann Spectrophotometer Model DU

抗原稀积で 28,000 倍宗で陽性を示した。以上の実験結 果から緑膿菌 autolysateよりイオン交換樹脂を用いて その内毒素を分離精製するととが出来た。又との内清素 は従来の autolysate 方ら分離される comp. I 上化学的 に同一のむのと考えられる。

\section{考 察}

縁膿菌草合成培地で $37^{\circ} \mathrm{C} 30$ 時間振湯培盖すると，その。 autolysate 中にはいわ功る内毒素である Lipopolysaccharide-protein complex (comp. I 已命名) は nucleic acids. polyribose phosphate (comp. II と命名) 及び塩基性物 質と結合した状態で存在していると考えられている。 lipopolysaccharide-protein complex (comp. I) 水溶液に $50 \% \mathrm{ZnCl}_{2}$ を滴下しても沈降物性じないが，前記 comp. I-comp. II-塩基珄物質複合体の状態では容易に沈. 降与る。従つて内表素 lipopolysaccharide-protein complex (comp. I) の精製に従来の蛋白の精製分離法である 塩化雨銛による沈澱法学用いるととが出来る。ついで comp. I は Dowex 50亿対し pH4万至10の範用で吸着 されないとと利用し（Fig. 2）この濃縮された comp. I-comp. II-監基性物質を Dowex 50 と弱アルカリ性で振 盪すると，とれらの各成分を解離させるととが出来， 塩基性物質泣変性し水に不溶亡なる。次に comp. I は Amberleite XE 64 亿対しては $\mathrm{pH} 2$ 乃至 $7 の$ 間て吸着 され弱アルカリ性では吸着されないので (Fig. 3) Dow. 
ex 50亿よつて解離した毒素液を滤別し, その滤液を稀 塩酸で pH 2.2 として Amberleite XE 64 (H型) を加 えると comp. I は之に吸着される。そこでとれを 0.4 $\mathrm{N}-\mathrm{NaOH}$ で中性にして溶出すれば comp. I が単離され るわけである。

この方法は従来の方法と比較すると, その精製過程で electrodialysis, zone electrophoresis を抢となう必要なく 容易に電気泳動的に均一な材料がえられる点に特長があ る。又 comp. I と核酸成分 comp. II との分離も容易で あるととは内毒素の精製に好都合である。

イオン交換樹脂はリボヌクレアーゼ, リゾチーム及び その他の蛋白質の精製に応用されているが緑膿菌の菌体 内毒素は分子量 100 万位の蛋白糖脂質複合体であり, こ のような高分子物質がレジンに対してその化学的生物学 的活性を失うととなく吸着溶出が可能であるととは興味 あるととである。

本間, 浜村及び著者らは緑膿菌ファージの精製に本論 交に使用したと同じレジンを用いて成功した。従来ファ ージの精製に当つて超遠心分離硫安分画あるいは有機 溶媒による分画沈澱法がおこなわれてきたが，この場合 内毒素などの高分子物質との分離は非常に困難であつ た。今回とのような高分子菌体内毒素がイオン交換樹脂 飞対して, その吸着溶出の態度が明らか儿されたために ファージと内毒素との分離がイオン交換樹脂によつて容 易に達成するととが出来た。

\section{結 論}

合成培地に培養した 緑膿菌培養滤液を濃縮し, 之に Dowex 50, Amberleite XE 64を用いて!毒素 (lipopolysaccharide-protein complex) を精製分離するととが出来 た。

本研究の一部は 1957 年 4 月松本で和となわれた日本 細菌学会関東支部会で発表された。また 1955 年 11 月東 京で扔てなわれた日本生化学総会で発表した。

終にのぞみ御校閲の労をとられ, その後の研究の御指 道に当られている恩師群馬大学医学部沢田利貞教授に対 し深謝する。文本論文の御指曾をいただいた東京大学伝 染病研究所本間遜助教授に感謝の意を表し, 同研究室の 捠村憲克氏その他の方々の御助力を感謝する。

\section{引用交献}

1) Boivin, A. and Mesrobeanu, L. : Rev. Immunol., 1, 553, 1935, 2, 113, 1936.

2）細谷省吾, 川島四郎：実験医学雑誌，20, 913,
1936.

細谷省吾, 進藤宙二, 門馬顕義 : 実験医学雑誌, 20, 1334, 1936.

細谷省吾, 川島四郎, 進藤宙二, 田中哲之助 : 第 11 回連合微生物学会記録, 119, 1937.

3) Morgan, W.T. J. : Biochem. J., 31, 2003, 1937.

4) Morgan, W. T. J. and Partridge, S. M. : Biochem. J., 35, 1140, 1941.

5) Palmer, J. W. and Gerlough, T. D. : Science, 92, 155, 1940.

6) Walker, J. : Biochem. J., 34, 325, 1940.

7）黒屋政泉和 : 東北医誌, 29, 231, 1941.

8）武田德晴, 大田達男, 佐藤稔 : 第 16 回連合微生 物学会記録, 116, 1942. J. Biochem., 36 '407, 1944.

9) Perlman, E., Binkley, F. and Goebel, W. F. : J. Bact., 47, 476, 1944.

Goebel, W. F., Binkley, F. and Perlman, E. : J. Exp. Med., 81, 315, 331, 349, 1945.

Tal. C. and Goebel, W.F. : J. Exp. Med., 92 $25,1950$.

10）細谷省吾, 本間遜, 林喬基礎と臨休，1，52$58,1947$.

11) Hosoya, S., Homma, Y., Egami, F. and Yagi, Y. : Japan J. Ep. Med., 20, 55-68, 1948.

12) Homma, Y., Hamamura, N., Naoi, M. et Egami, F. : Imprimé avec le périodique «Bulletin de la Société de Chemie biologique $\gg$ Extrait du Tome XL, n4, 647-664, 1958.

13) Homma, J. Y., Sagehashi, K., et Hosoya, S. : Japan. J. Exp. Med., 21, 375, 1951.

14) Homma, J. Y., Katsura, T., Hosoya, S., Miyazaki, Y., Kimura, K. et Saito, N. : Annual Report of the Research Commitee on the Application of Artificial Radioactive Isotopes in Japan, 2-1, 91, 1952.

15) Homma, J. Y. : Jap. J. Exp. Med., 22, 17, 1952.

16) Homma, J. Y., Katsura, T., Sagehashi, K. et Hosoya, S. : Jap. J. Allergy, 3, 136, 1954.

17) Homma, J.Y., Katsura, T., Sagehashi, K., Hosoya, S.; Miyazaki, Y. et Wakabayashi, Y. : Jap. J. Allergy, 3, 177, 1954.

18) Egami, F., Shimomura, M., Ishihara, H., Homma, J.Y., Sagehashi, K. et Hosoya, S. : Bull. Soc. Chim. Biol., 36, 779, 1954.

19) Naoi, M., Egami, F., Hamamura, N. und Homma, J.Y. : Biochemische Zeitschrift, 330, 421 $-427,1958$.

20) 本間遜, 捧橋孝, 細谷省吾, 江上不二夫, 下村道夫, 石原宏：日本細菌学雑誌，9，1013，1954.

21) Lowry, O.H. : J. Biol. Chem., 193, 265, 1951

22) Allen, R. J. L. : Biochem. J. 34, 858, 1940. (受付：1959 年 12 月 4 日) 